\title{
OSZCZĘDNOŚCI GOSPODARSTW DOMOWYCH OSIĄGAJĄCYCH DOCHODY O NISKIEJ UŻYTECZNOŚCI
}

\begin{abstract}
Celem artykułu jest prezentacja wielkości oszczędności, jakie kreować mogą gospodarstwa domowe uzyskujące dochody oceniane jako mało użyteczne. Analizą objęto podstawy teoretyczne procesu pomiaru użyteczności dochodów oraz prezentację sytuacji w zakresie oszczędności w grupie gospodarstw uzyskujących dochody określane jako nisko użyteczne. Część empiryczną artykułu oparto na wynikach własnego projektu badawczego „Badanie użyteczności dochodów polskich gospodarstw domowych i ich wpływu na zachowania gospodarstw” realizowanego przez Stowarzyszenie „Centrum Wspierania Edukacji i Przedsiębiorczości”. Analizę statystyczną przeprowadzono na danych pochodzących z badania Budżetów Gospodarstw Domowych prowadzonych przez Główny Urząd Statystyczny. Artykuł stanowi opracowanie własne na podstawie danych liczbowych GUS. Główny Urząd Statystyczny nie ponosi odpowiedzialności za wnioski zawarte w publikacji. Uzyskane wyniki wskazują, że uzyskiwanie dochodów ocenianych jako mniej użyteczne nie musi wykluczać pojawienia się oszczędności w takich gospodarstwach domowych. Odsetek gospodarstw oszczędzających wzrasta wraz z przechodzeniem na wyższe stopnie oceny użyteczności dochodów. Również wartość nominalna oszczędności wzrasta wraz z przechodzeniem do grupy gospodarstw oceniających swoje dochody jako bardziej użyteczne.

Slowa kluczowe: dochody, oszczędności, gospodarstwa domowe, użyteczność dochodów, metoda lejdejska.
\end{abstract}

\section{WPROWADZENIE}

Ekonomiczna kategoria użyteczności opisuje subiektywną własność dóbr lub usług, która ma odzwierciedlać poziom satysfakcji, jakiego dostarczyć może ich konsumpcja ${ }^{2}$. Obecnie w teorii ekonomii dość często mówi się o użyteczności dochodów. Zgodnie z I prawem Gossena użyteczność pieniądza wraz ze wzrostem wielkości uzyskiwanego dochodu do dyspozycji powinna spadać. Jeżeli jednak podstawowe potrzeby nie są zaspokojone, to każda dodatkowa jednostka pieniądza może wykazywać się wzrastającą użytecznością krańcową. Na

\footnotetext{
${ }^{1}$ Dr Elżbieta Szczygieł, Stowarzyszenie „Centrum Wspierania Edukacji i Przedsiębiorczości”, Rzeszów, e-mail: elzbieta.szczygiel@gmail.com

${ }^{2}$ Pierwsze wzmianki o użyteczności pojawiają się $\mathrm{w}$ kontekście powstania rachunku prawdopodobieństwa, w pismach Blaise'a Pascala, oraz w pracach Gabriela Cramera i Daniela Bernoulliego. W ekonomii użyli go po raz pierwszy Samuel Pufendorf i Ferdinando Galiani, do angielskiej ekonomii zaś wprowadził go Jeremy Bentham, który definiował użyteczność jako doświadczalną przyjemność $\mathrm{z}$ konsumpcji danego dobra i rezultatów z tą przyjemnością związanych. Por. D. Bernoulli, Exposition of a new theory on the measurement of risk, „Econometrica” 22/1 (1954), s. 23-36 (powtórne wydanie oryginału); P.J.H. Schoemaker, The Expected Utility Model: Its Variants, Purpose, Evidence and Limitation, „Journal of Economic Literature" 1982/XX, s. 529-563; D. Khaneman, R.H. Theler, Anomalies: Utility Maximization and Experienced Utility, „Journal of Economic Perspectives” 20/1 (2006), s. 222-223.
} 
istnienie tej zależności zwrócili uwagę Arie Kapteyn i Tom Wansbeek, wykazując, że nie jest ona podstawą do uchylenia I prawa Gossena, ale że jest to własność wręcz pożądana ${ }^{3}$. Pomiar użyteczności dochodów odbywa się obecnie na podstawie danych uzyskiwanych od samych gospodarstw domowych, które mają możliwość dokonania werbalnej oceny poziomu uzyskiwanego dochodu oraz odniesienia poszczególnych ocen użyteczności do poziomu dochodów hipotetycznych (szerzej o pomiarze w dalszej części artykułu). Od poziomu oceny użyteczności realnego dochodu może zależeć wiele decyzji gospodarstwa domowego, w tym o odroczeniu konsumpcji, czyli kreowaniu oszczędności w danym okresie. Celem przeprowadzonego badania empirycznego stanowiącego przedmiot artykułu było uzyskanie odpowiedzi na pytanie, na ile czynnik, jakim jest ocena użyteczności danego, faktycznie uzyskiwanego dochodu, może wpływać na kreowanie oszczędności przez gospodarstwa domowe. Próbując zrealizować ten cel badawczy, przyjęto dwie hipotezy badawcze:

H1: osiąganie dochodów ocenianych jako mniej użyteczne może nie wykluczać kreowania oszczędności.

H2: wzrastającemu poziomowi użyteczności dochodów towarzyszy wzrastające prawdopodobieństwo kreowania oszczędności.

W celu weryfikacji zaprezentowanych hipotez wykorzystano dane nieidentyfikowane pochodzące $\mathrm{z}$ badania budżetów gospodarstw domowych przeprowadzonego przez Główny Urząd Statystyczny (GUS) za rok 2012. Prezentowane wyniki badania nawiązują także do wcześniejszej analizy wpływu oceny użyteczności dochodu na wielkość oszczędności gospodarstw domowych, jakie autorka zaprezentowała w pracy pt. Ocena użyteczności dochodu $i$ jej wplyw na oszczędności gospodarstw domowych ${ }^{4}$. Wspomniane opracowanie obejmowało jednak lata 2003-2009 i dotyczyło wszystkich poziomów oceny, zaś kwestie oceny w obecnie analizowanej grupie dochodowej zostały przedstawione jedynie sygnalnie. Niniejszy artykuł stanowi rozwinięcie i pogłębienie analizy podjętego uprzednio tematu poprzez opracowanie danych dla roku 2012 oraz zastosowanie poszerzonej analizy zjawiska dla gospodarstwach domowych osiągających dochody oceniane jako użyteczne w niskim stopniu.

\section{MODEL POMIARU UŻYTECZNOŚCI DOCHODÓW}

Możliwość bezpośredniego pomiaru użyteczności dochodu została zaproponowana przez Bernarda M.S. van Praaga w roku $1968^{5}$. Metoda ta opiera się na estymacji funkcji

\footnotetext{
${ }^{3}$ Jak wskazuje Stanisław M. Kot za Arie Kapteynem i Tomem Wansbeekiem (S.M. Kot, Modelowanie poziomu dobrobytu. Teoria i zastosowanie, Zakład Narodowy im. Ossolińskich, Wrocław-Warszawa-Kraków 1995, s. 47, [cyt. za:] A. Kapteyn, T. Wansbeek, The Individual Welfare Function, „Journal of Economic Psychology” 1985/6, s. 333-363), nie pojawia się w literaturze przedmiotu żadne empiryczne potwierdzenie przebiegu funkcji użyteczności krańcowej w sposób opisywany przez Hermanna Heinricha Gossena, a więc o ujemnym nachyleniu tej funkcji. ${ }^{4}$ E. Szczygieł, Ocena użyteczności dochodu i jej wptyw na oszczędności gospodarstw domowych, WNT, Warszawa 2014.

${ }^{5}$ Nazwa Model lejdejski lub Metoda lejdejska pochodzi od Uniwersytetu w Lejdzie, z którym związani byli badacze. Koncepcję tę opisał w pracy doktorskiej B.M.S. van Praaga, Individual Welfare Functions and Consumer Behavior - a Theory of Rational Irrationality, North-Holland Publishing Company, Amsterdam 1968, Contributions to Economic Analysis, nr 57.
} 
użyteczności o wybranym modelu ${ }^{6}$ na podstawie wyników obserwacji bezpośredniej prowadzonej za pomocą specjalnie skonstruowanych pytań. Respondenci są proszeni w ankiecie o wskazanie konkretnego poziomu dochodu (hipotetycznego), jakiemu będzie odpowiadać określona na skali werbalnej ocena. W badaniach prowadzonych przez van Praaga skala werbalna przyjmowała sześć wartości ${ }^{7}$ : 1) bardzo zły, 2) zły, 3) niewystarczający, 4) wystarczający, 5) dobry, 6) bardzo dobry. W badaniach prowadzonych przez Główny Urząd Statystyczny skala miała pięć wartości ${ }^{8}$ : 1) bardzo zły, 2) niewystarczający, 3) ledwo wystarczający, 4) dobry, 5) bardzo dobry. Respondent jest dodatkowo proszony o wskazanie okresu, do jakiego odnoszą się udzielone odpowiedzi (np. okres tygodniowy, miesięczny lub roczny). W badaniu GUS jest to zawsze miesiąc. Każda z udzielonych odpowiedzi stanowi tzw. wirtualny poziom dochodu oznaczany przez badaczy jako $x_{i j}$, gdzie $i$ jest numerem werbalnej oceny dochodu $(i=1,2, \ldots, n), j$ zaś określa numer respondenta (lub gospodarstwa domowego; $j=1,2, \ldots, n)$. Po udzieleniu odpowiedzi powstaje skala kategorialna, w której na podstawie wskazywanych poziomów dochodów tworzone są granice między poszczególnymi kategoriami. Wskazane przez respondenta poziomy dochodu wirtualnego $x_{i j}$ będą zależeć od faktycznie uzyskiwanego dochodu $y_{j}$. Wynika $\mathrm{z}$ tego, że poszczególne oceny werbalne dochodu będą traktowane jako bodźce, na których wystąpienie reaguje respondent.

\section{ROZKŁAD UŻYTECZNOŚCI DOCHODÓW POLSKICH GOSPODARSTW DOMOWYCH}

$\mathrm{Na}$ podstawie danych nieidentyfikowanych pochodzących $\mathrm{z}$ badania budżetów gospodarstw domowych w roku 2012 dokonano modelowania wykresów funkcji użyteczności $\mathrm{Z}$ wykorzystaniem rozkładu log-normalnego. Na rysunku 1 przedstawiono funkcję użyteczności krańcowej dochodów uzyskiwanych przez gospodarstwa domowe ogółem w 2012 roku.

\footnotetext{
${ }^{6} \mathrm{~W}$ literaturze przedmiotu jako podstawowe funkcje służące do estymacji funkcji użyteczności wskazuje się rozkład logarytmiczno-normalny, rozkłady Burra typu III i XII (Daguma i SinghaMaddali) oraz rozkład log-logistyczny (Fiska). Por. E.J.S. Plug, B.S.M. van Praag, J. Hartog, Household equivalence scales and household taxation, Working Paper University of Amsterdam 1998, s. 2; B.M.S. van Praag, P. Frijters, The measurement of welfare and well-being. The Leyden approach, [w:] Well-Being. The Fondations of Hedonic Psychology, red. D. Khanemen, E. Diner, N. Schwarz, Russel Sage Foundation, New York 2003, s. 422; S.M. Kot, Ekonometryczne modele dobrobytu, Wydawnictwo Naukowe PWN, Warszawa 2000, s. 72; E. Szczygieł, Ocena użyteczności dochodu i jej wpływ na oszczędności gospodarstw domowych, WNT, Warszawa 2014.

${ }^{7}$ Skala za: B.M.S. van Praag, An integration of the two dimensions of the welfare concept, [w:] The Measurement of Household Welfare, red. R. Blundell, I. Preston, I. Walker, Cambridge University Press, Cambridge 1994, s. 92. W literaturze można spotkać również skale alternatywne - por. Y. Amiel, The Subjective Approach to the Measurement of Income Inequality, „Distributional Analysis Research Programme Discussion Papers" London School of Economics, London 1998/38, s. 8; B.M.S. van Praag, The Welfare Function of Income In Belgium: An Empirical Investigation, „European Economic Review” 1971/2, s. 337-369; B.M.S. van Praag, A. Kapteyn, Further Evidence on The Individual Welfare Function of Income: An Empirical Investigation in The Netherlands, „European Economic Review” 1973/4, s. 33-62.

${ }^{8}$ Karta statystyczna gospodarstwa domowego (BR-01a), dział 6: Opinia respondenta o warunkach życia gospodarstwa domowego.
} 
Rys. 1. Funkcja użyteczności krańcowej dochodów dla gospodarstw domowych w 2012 r.

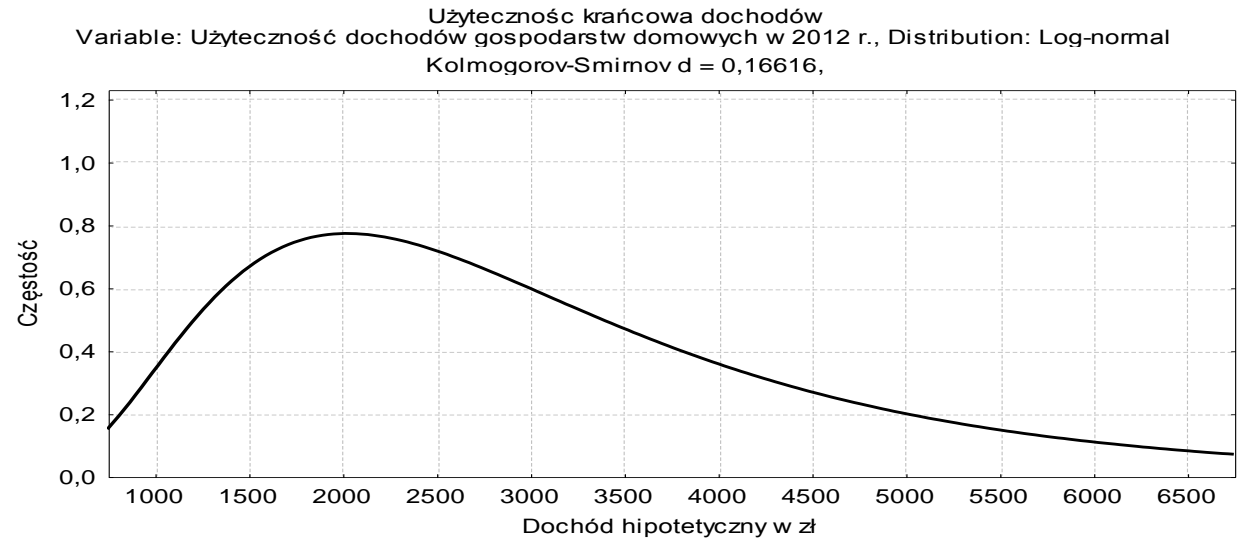

Źródło: opracowanie własne.

Przy szacowaniu dopasowania funkcji wykorzystano rozkład logarytmiczno-normalny. Wartość dochodów ocenianych jako bardziej użyteczne wzrasta systematycznie, co obrazuje spłaszczenie wykresu użyteczności krańcowej, by w końcowych wartościach największego dochodu opadać znacznie wolniej (wykres użyteczności całkowitej byłby przesunięty w prawo).

Przyjęto, że dochodami o niskiej użyteczności będą:

- dochody niższe niż dochód oceniany jako „bardzo zły” (poniżej C1);

- dochody niższe niż dochód oceniany jako „niewystarczający” (C1-C2);

- dochody niższe niż dochód oceniany jako ,ledwo wystarczający” (C2-C3).

Przedziały te są obustronnie domknięte, co zapewnia możliwość analizy poszczególnych zbiorów pojedynczo, a nie kumulatywnie. Przyjęcie takiego założenia pozwala na wskazanie trzech odrębnych grup dochodów o określonych parametrach rozkładów (tab. 1).

W pierwszej grupie znalazły się faktyczne dochody uzyskiwane przez gospodarstwa domowe na poziomie niższym niż dochód hipotetyczny oceniany przez dane gospodarstwo jako „bardzo zły”. Średnia wartość dochodu w tej grupie wyniosła 894 zł. Ponieważ wzięto pod uwagę wszystkie deklarowane odpowiedzi, znalazły się wśród nich także informacje o ujemnym dochodzie oraz dochodzie na poziomie 0 zł. Stąd pierwszy decyl osiągnął wartość 5 zł. Mediana dochodów wyniosła nieco poniżej 1 tys. zł, różnica między najniższym a najwyższym decylem zaś sięgnęła prawie 2 tys. zł. Wartość współczynnika zmienności $(V)$ wskazuje, że zróżnicowanie dochodów jest statystycznie istotne ( $>10 \%)$. W tej grupie gospodarstw asymetria rozkładu jest asymetrią lewostronną, o czym świadczy ujemna wartość współczynnika asymetrii (A). Ostatni z kluczowych parametrów opisowych rozkładu dochodów w analizowanych grupach - współczynnik kurtozy - wskazuje na dość dużą koncentrację dochodów uzyskiwanych przez gospodarstwa w tej grupie dochodowej wokół wartości średniej (w porównaniu $\mathrm{z}$ pozostałymi dwiema grupami) i może świadczyć o platokurtyczności rozkładu (rys. 2A). 
Tabela 1. Statystyki opisowe dla rozkładów dochodów hipotetycznych w trzech grupach

\begin{tabular}{|l|r|r|r|r|r|r|}
\hline & $\bar{x}$ & \multicolumn{1}{c|}{$M e$} & \multicolumn{1}{c|}{$Q_{1}$} & \multicolumn{1}{c|}{$Q_{3}$} & \multicolumn{1}{c|}{ Decyl } & 9 Decyl \\
\hline$<\mathrm{C} 1$ & 894 & 998 & 590 & 1467 & 5 & 1971 \\
\hline $\mathrm{C} 1-\mathrm{C} 2$ & 1719 & 1519 & 1163 & 2028 & 932 & 2697 \\
\hline $\mathrm{C} 2-\mathrm{C} 3$ & 2218 & 2013 & 1527 & 2645 & 1172 & 3423 \\
\hline & $\zeta$ & $V$ & $\sigma$ & $\sigma$ & $A$ & $K$ \\
\hline$<\mathrm{C} 1$ & 33,4 & 203,6 & 3316678 & 1821,2 & $-9,1$ & 135,6 \\
\hline $\mathrm{C} 1-\mathrm{C} 2$ & 14,9 & 50,4 & 750423 & 866,3 & 2,8 & 18,7 \\
\hline $\mathrm{C} 2-\mathrm{C} 3$ & 14,5 & 49,7 & 1216847 & 1103,1 & 3,2 & 26,9 \\
\hline
\end{tabular}

Źródło: opracowanie własne.

Rys. 2. Rozkład dochodów niższych niż „bardzo złe”, „niewystarczające” oraz „ledwo wystarczające"

A. Dochody niższe niż „,bardzo złe”

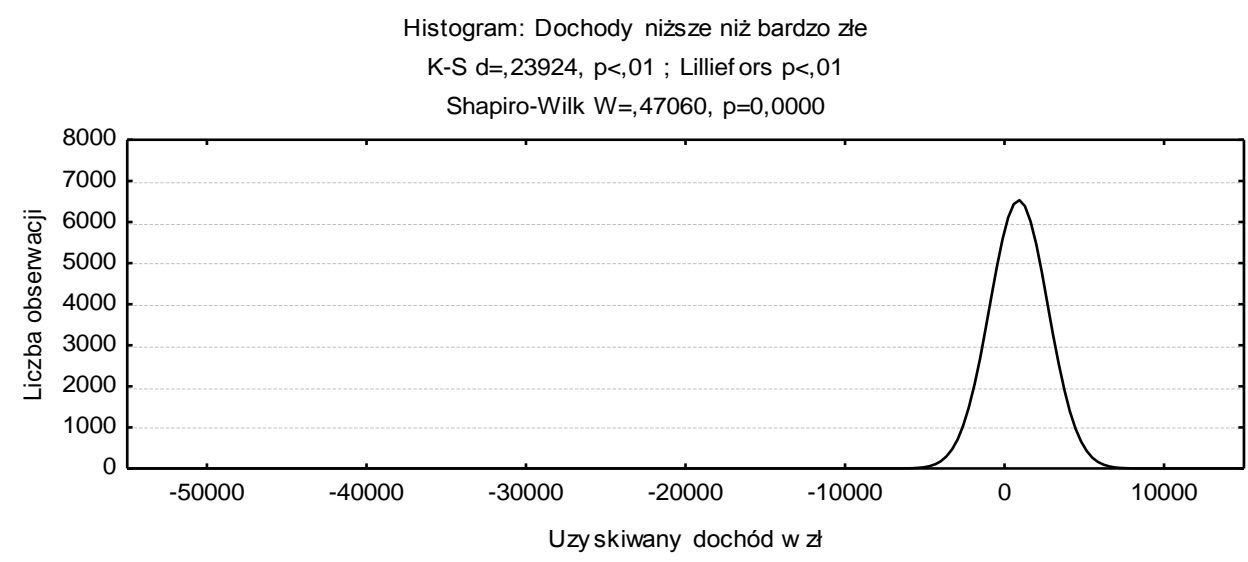

B. Dochody niższe niż „niewystarczające”

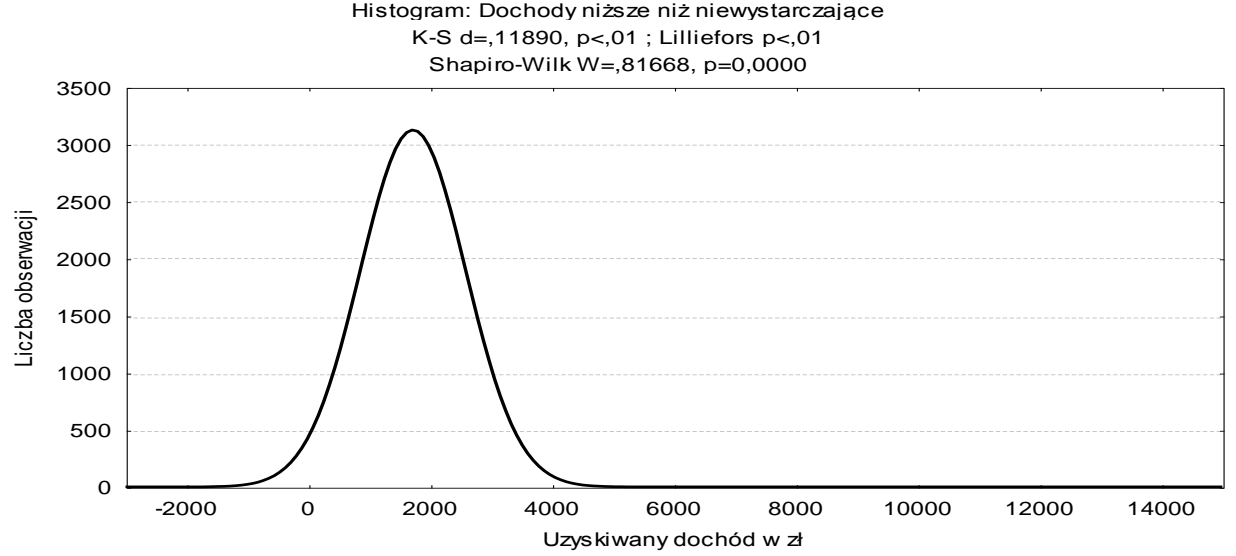


C. Dochody niższe niż „ledwo wystarczające”

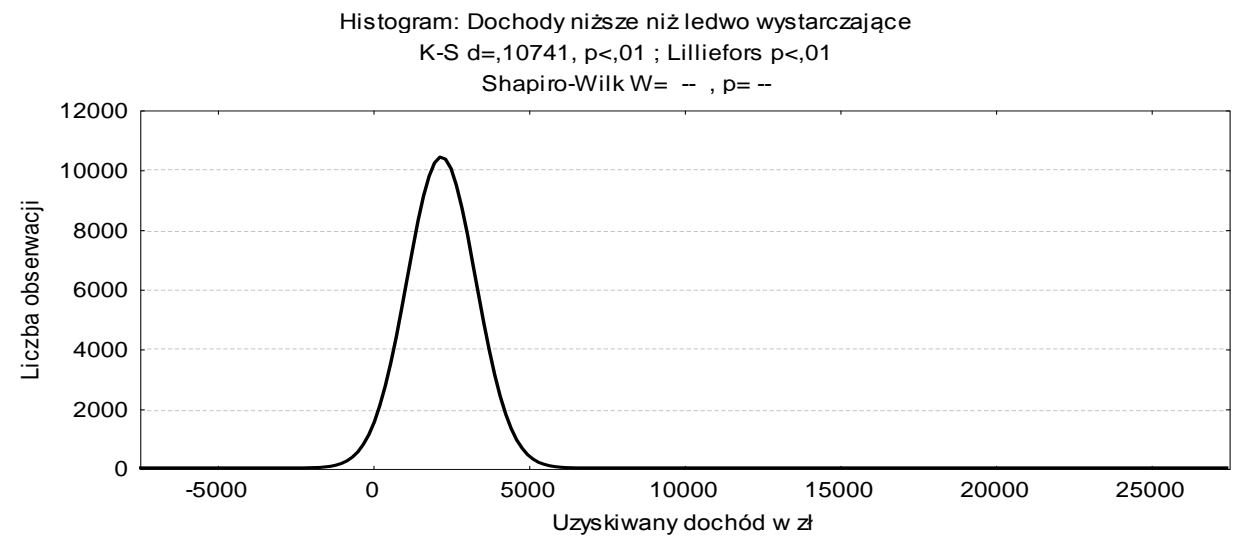

Źródło: opracowanie własne.

W drugiej grupie znalazły się faktyczne dochody uzyskiwane przez gospodarstwa domowe na poziomie niższym niż dochód hipotetyczny oceniany przez dane gospodarstwo jako „niewystarczające”. Średnia wartość dochodu faktycznie uzyskiwanego w tej grupie wyniosła ponad 1700 zł i była dwukrotnie większa niż w pierwszej grupie dochodowej. Pierwszy decyl dochodów wyniósł ponad $900 \mathrm{zł}$, dziewiąty zaś był od niego wyższy o prawie $1800 \mathrm{zł}$. W porównaniu z pierwszą grupą dochodową wartość współczynnika zmienności była znacznie niższa, choć jego poziom jest nadal statystycznie istotny. W tej grupie gospodarstw asymetria rozkładu jest asymetrią prawostronną, o czym świadczy dodatnia wartość współczynnika asymetrii $(A)$. Asymetria ta nie jest też znacząca, co może świadczyć o dużej symetryczności dochodów w tej grupie. Wartość współczynnika kurtozy wskazuje na niską koncentrację dochodów uzyskiwanych przez gospodarstwa w tej grupie dochodowej wokół wartości średniej (rys. 2B).

W ostatniej grupie gospodarstw znalazły się te, których faktyczne dochody były na poziomie niższym niż dochód hipotetyczny oceniany przez dane gospodarstwo jako ,ledwo wystarczający". Średnia wartość dochodu faktycznie uzyskiwanego w tej grupie wyniosła ponad 2200 zł i była prawie trzykrotnie większa niż w pierwszej grupie dochodowej. Pierwszy decyl dochodów wyniósł prawie 1200 zł, dziewiąty - ponad 3400 zł. W porównaniu z pierwszą grupą dochodową wartość współczynnika zmienności była znacznie niższa, choć jego wartość jest nadal statystycznie istotna (wartość ta była zbliżona do wartości w drugiej grupie dochodowej). Podobną wartość jak w drugiej grupie osiągały też wartości współczynników asymetrii i kurtozy (rys. 2C).

Analizując wartości poszczególnych dochodów hipotetycznych, ocenianych przez gospodarstwa w każdej z grup dochodowych, można wskazać, że wartości dochodów nie są oceniane proporcjonalnie ani też zmiany oceny nie zachodzą stopniowo (tab. 2). 
Tabela 2. Wartości dochodów hipotetycznych w poszczególnych przedziałach dochodowych (zł)

\begin{tabular}{|l|c|c|c|}
\hline Dochód hipotetyczny & $<\mathrm{C} 1$ & $\mathrm{C} 1-\mathrm{C} 2$ & $\mathrm{C} 2-\mathrm{C} 3$ \\
\hline Bardzo zły & 1628,63 & 1416,86 & 1367,87 \\
\hline Niewystarczający & 2030,95 & 1948,84 & 1851,15 \\
\hline Ledwo wystarczający & 2515,48 & 2482,23 & 2558,57 \\
\hline Dobry & 3737,01 & 3674,59 & 3862,59 \\
\hline Bardzo dobry & 5264,91 & 5142,42 & 5457,5 \\
\hline
\end{tabular}

Źródło: opracowanie własne na podstawie Budżetów gospodarstw domowych z 2012 r.

W przypadku dochodów hipotetycznych ocenianych przez gospodarstwa uzyskujące dochody niższe niż wskazywane przez nie dochody „bardzo złe” ich wartość we wszystkich ocenach werbalnych jest wyższa niż w przypadku dochodów ocenianych przez gospodarstwa uzyskujące dochody wyższe niż „,bardzo złe”, a niższe niż „,niewystarczające”. Wynikać to może $\mathrm{z}$ dużego stopnia deprywacji materialnej w tego typu gospodarstwach, które próbują w ten sposób również „odrobić” dotychczasowe straty dochodowe (w tym permanentne uzyskiwanie dochodów niższych niż pozwalające zaspokoić podstawowe potrzeby). W przypadku ocen dochodów hipotetycznych dokonywanych przez gospodarstwa uzyskujące dochody niższe niż ,niewystarczające” wartości dla poszczególnych ocen werbalnych są niższe niż w przypadku ocen wystawianych przez pierwszą grupę gospodarstw, co może sugerować pewien stopień zaspokojenia niektórych potrzeb i brak jednoznacznej potrzeby „odrobienia” dotychczasowych niskich dochodów i potencjalnego dyskomfortu życiowego z tym związanego. W przypadku gospodarstw domowych uzyskujących dochody niższe niż oceniane jako „ledwo wystarczające”, a wyższe niż „niewystarczające”, wartości dochodów hipotetycznych są większe niż w grupie drugiej dopiero od dochodów „ledwo wystarczających” (rys. 3).

Rys. 3. Wartości dochodów dla użyteczności całkowitej w trzech analizowanych grupach

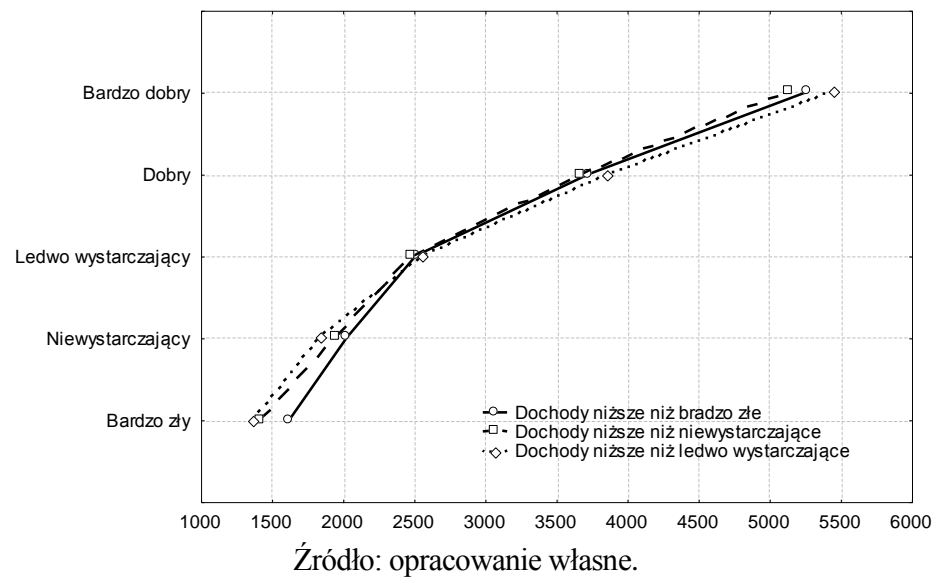


Tabela 3. Ocena współczynników korelacji między logarytmem faktycznych dochodów a logarytmami ocen dochodów hipotetycznych w badanych grupach dochodowych

\begin{tabular}{|l|c|c|c|c|c|}
\hline \multicolumn{1}{|c|}{ Dochód faktyczny } & $\ln (\mathrm{C} 1)$ & $\ln (\mathrm{C} 2)$ & $\ln (\mathrm{C} 3)$ & $\ln (\mathrm{C} 4)$ & $\ln (\mathrm{C} 5)$ \\
\hline < C1 & 0,26 & 0,19 & 0,13 & 0,04 & $-0,03$ \\
\hline $\mathrm{C} 1-\mathrm{C} 2$ & 0,92 & 0,97 & 0,92 & 0,81 & 0,70 \\
\hline $\mathrm{C} 2-\mathrm{C} 3$ & 0,85 & 0,95 & 0,96 & 0,85 & 0,75 \\
\hline
\end{tabular}

W tabeli 3 zaprezentowano ocenę współczynników korelacji między logarytmem faktycznym dochodów a logarytmem dochodów hipotetycznych w badanych grupach dochodów. Korelacja ta obrazuje stopień łatwości dokonywania operacji na określonym poziomie dochodów. W tym wypadku wyższe poziomy korelacji świadczą o łatwości dokonywania operacji (w tym oceny określonej wartości dochodów) na wartościach bliższych poziomowi faktycznego dochodu uzyskiwanego przez nie. W pierwszej grupie dochodowej (< C1), mimo niskiej wartości współczynnika korelacji, jest on najwyższy dla wartości logarytmów dochodów ocenianych jako „bardzo złe” (C1). Podobnie w drugiej grupie dochodowej (C1-C2), wartość współczynnika jest najwyższa dla logarytmu dochodów ocenianych jako „niewystarczające” (C2). W trzeciej grupie dochodowej (C2-C3) wartość ta jest najwyższa dla logarytmów dochodów ocenianych jako „niewystarczające” (C3).

\section{WYNIKI ANALIZY WARTOŚCI OSZCZĘDNOŚCI GOSPODARSTW DOMOWYCH WZGLĘDEM OCEN UŻYTECZNOŚCI DOCHODÓW}

Biorąc pod uwagę trzy grupy dochodowe gospodarstw domowych, dokonano oszacowania wartości oszczędności, jakie gospodarstwa te kreują. W tabeli 4 przedstawiono statystyki opisowe dla oszczędności w każdej z grup.

Tabela 4. Statystyki opisowe dla rozkładów oszczędności ogółem w trzech grupach

\begin{tabular}{|l|c|c|c|c|c|c|c|}
\hline & $\bar{x}$ & $M e$ & $Q_{1}$ & $Q_{3}$ & l Decyl & 9 Decyl & $\zeta$ \\
\hline <C1 & -1333 & -727 & -1535 & -307 & -3010 & 29 & 44,6 \\
\hline C1-C2 & -604 & -421 & -959 & -3 & -1718 & 352 & 20,0 \\
\hline C2-C3 & -322 & -175 & -752 & 296 & -1465 & 721 & 17,8 \\
\hline & Min & Max & $V$ & $\sigma$ & $\sigma$ & $A$ & $K$ \\
\hline <C1 & -42711 & 7140 & $-182,8$ & 5940213 & 2437,3 & $-6,9$ & 76,7 \\
\hline C1-C2 & -22298 & 4864 & $-193,3$ & 1360825 & 1166,5 & $-4,5$ & 56,6 \\
\hline C2-C3 & -40013 & 10976 & $-418,1$ & 1815151 & 1347,3 & $-7,4$ & 163,4 \\
\hline \multicolumn{7}{|c|}{ Zródło: opracowanie własne }
\end{tabular}

Zaprezentowane wyniki potwierdzają zależność wzrostu oszczędności w miarę wyższej oceny użyteczności całkowitej dochodu. Należy jednak zauważyć, że wzrost ten nie jest równomierny przy przechodzeniu do wyższej oceny użyteczności. Jest to o tyle istotne, ponieważ wyznaczając długości przedziałów werbalnej skali ocen, GUS przyjął założenie, że odległości między krańcami przedziałów są równe.

W pierwszej grupie dochodowej, w której gospodarstwa uzyskują dochody niższe niż dochody hipotetyczne oceniane przez nie jako „bardzo złe”, średnia wartość oszczędności jest ujemna, a tym samym dług tych gospodarstw wynosi ponad $700 \mathrm{zł}$. Maksymalne zadłużenie wyniosło ponad 42 tys. zł, podczas gdy maksymalna wartość oszczędności wyniosła nieco ponad $7100 \mathrm{zł}$. Pierwszy i trzeci kwartyl dla wartości oszczędności również osiągały wartości ujemne, co oznacza, że 75\% gospodarstw należących do tej grupy generuje długi, nie zaś 
oszczędności. Wartość pierwszego decyla wyniosła ponad 3 tys. zł długu, dodatnią wartość oszczędności wykazał jedynie dziewiąty decyl. Wartość współczynnika asymetrii wskazuje na asymetrię lewostronną rozkładu. Rozkład wykazuje się umiarkowaną wartością kurotzy, choć można stwierdzić, że jest to rozkład smukły.

W drugiej grupie dochodowej, w której znajdują się gospodarstwa osiągające dochody wyższe niż oceniane przez siebie jako „bardzo złe”, jednak niższe niż „niewystarczające”, średnia wartość oszczędności jest ujemna, a poziom tego zadłużenia jest o połowę niższy niż w przypadku grupy pierwszej. Także mediana oszczędności wskazuje na zadłużenie ponad 50\% gospodarstw. Co ciekawe, w tej grupie dochodowej także $75 \%$ gospodarstw jest zadłużonych, choć wartość trzeciego kwartyla to tylko 3 złote długu. Gospodarstwa należące do dziewiątego decyla generują już oszczędności o wartości przekraczającej 350 zł. Maksymalne zadłużenie w tej grupie było o połowę niższe niż $\mathrm{w}$ grupie pierwszej, jednak maksymalny poziom oszczędności był niższy i wynosił nieco ponad 4800 zł. Rozkład był przesunięty w prawo względem rozkładu dla grupy pierwszej, choć nadal był rozkładem lewostronnie asymetrycznym. Kurtoza rozkładu była niższa, co może świadczyć o większym spłaszczeniu rozkładu i mniejszej koncentracji wokół wartości średniej, na co też wskazuje niższa wartość wariancji niż w grupie pierwszej.

W trzeciej grupie dochodowej, w której gospodarstwa uzyskują dochody wyższe niż oceniane przez siebie jako „niewystarczające”, a niższe niż oceniane jako „ledwo wystarczające", średnia wartość oszczędności również była ujemna. Zadłużenie tych gospodarstw wynosiło 322 zł. Podobnie też mediana wskazywała, że w tej grupie było sporo gospodarstw zadłużonych, choć wartość tego zadłużenia wynosiła w tym przypadku 175 zł. Trzeci kwartyl gospodarstw generował już jednak oszczędności w wysokości prawie $300 \mathrm{zł}$, gospodarstwa należące do 9 decyla zaś osiągały je już wysokości ponad 700 zł. Maksymalne zadłużenie $\mathrm{w}$ tej grupie dochodowej gospodarstw wynosiło ponad 40 tys. zł. Maksymalny poziom generowanych oszczędności wyniósł prawie 11 tys. zł. Te wartości spowodowały, że rozkład jest jednak przesunięty znacznie bardziej w lewo niż rozkłady dla dwóch poprzednich grup, choć jest on znacznie bardziej skoncentrowany wokół wartości średnich niż te grupy, o czym świadczy wartość współczynnika kurtozy.

Analizując liczbę gospodarstw kreujących oszczędności w każdej z grup dochodowych, można stwierdzić, że odsetek takich gospodarstw wzrasta wraz z przechodzeniem do grupy uzyskującej dochody w wyższej ocenie użyteczności (tab. 5). W pierwszej grupie dochodowej zaledwie $10 \%$ gospodarstw kreowało oszczędności. $\mathrm{W}$ porównaniu $\mathrm{z}$ danymi pochodzącymi z lat ubiegłych jest to wyraźny spadek. W roku 2003 takich gospodarstw w tej grupie dochodowej było aż $29 \%$, podczas gdy w 2009 r. odnotowano ich aż $40 \%$. W drugiej grupie dochodowej co czwarte gospodarstwo kreowało oszczędności, i znów - w porównaniu z latami ubiegłymi - był to wyraźny spadek. W roku 2003 gospodarstw takich było $45 \%$, w 2009 zaś - aż 58\%. W trzeciej analizowanej grupie dochodowej nieco ponad 40\% wszystkich gospodarstw kreowało oszczędności, jednak było to znów mniej w porównaniu z latami ubiegłymi (odpowiednio o $15 \%$ mniej w stosunku do 2003 r. i o $25 \%$ mniej w stosunku do 2009 r. $)^{9}$.

\footnotetext{
${ }^{9}$ E. Szczygieł, op. cit., s. 106-107.
} 
Tabela 5. Statystyki opisowe dla rozkładów oszczędności dodatnich w trzech grupach

\begin{tabular}{|l|c|c|c|c|c|c|c|}
\hline & Odsetek $^{*}$ & $\bar{x}$ & $M e$ & $Q_{1}$ & $Q_{3}$ & 1 Decyl & 9 Decyl \\
\hline <C1 & 10,7 & 338 & 208 & 95 & 428 & 39 & 662 \\
\hline C1-C2 & 24,9 & 408 & 268 & 123 & 522 & 40 & 902 \\
\hline C2-C3 & 40,8 & 555 & 397 & 183 & 715 & 80 & 1150 \\
\hline & Min & Max & $V$ & $\sigma^{2}$ & $\sigma$ & $A$ & $K$ \\
\hline$<$ C1 & 1 & 7140 & 153,9 & 270447,3 & 520,0 & 7,9 & 93,4 \\
\hline C1-C2 & 1 & 4864 & 120,1 & 240518,4 & 490,4 & 3,6 & 20,0 \\
\hline C2-C3 & 0 & 10976 & 113,3 & 394836,6 & 628,4 & 5,1 & 52,8 \\
\hline
\end{tabular}

* - odsetek z ogólnej liczby gospodarstw w danej grupie dochodowej

Źródło: opracowanie własne.

Przy przechodzeniu do grupy, która osiągała dochody wyżej oceniane, wzrosła również średnia wartość oszczędności. W przypadku gdy w pierwszej grupie dochodowej wynosiła ona ponad 330 zł, w trzeciej była równa już ponad 550 zł. Wzrost tych wartości nie jest jednak proporcjonalny i jest większy między drugą a trzecią grupą dochodową. Najlepiej widać to również między wartościami pierwszego decyla w każdej z trzech grup. Między pierwszą a drugą jest to zaledwie $1 \mathrm{zł}$, podczas gdy między drugą a trzecia - $40 \mathrm{zł}$, czyli nastąpił wzrost o $100 \%$ w stosunku do wartości pierwszego decyla dla grupy drugiej. Podobnie też dla trzeciego decyla wzrost między pierwszą a drugą grupą wynosi prawie $100 \mathrm{zl}$, podczas gdy między drugą a trzecią - dwukrotnie więcej. Jednak w wypadku dziewiątego decyla wzrost między pierwszą a drugą grupą oraz między drugą a trzecią wyniósł w obu przypadkach około $250 \mathrm{zł}$. Rozbieżności te wynikają ze zróżnicowania rozkładów oszczędności w poszczególnych grupach dochodowych (rys. 4A-C).

Wykres 4. Rozkłady oszczędności dodatnich w każdej grupie dochodowej

A.

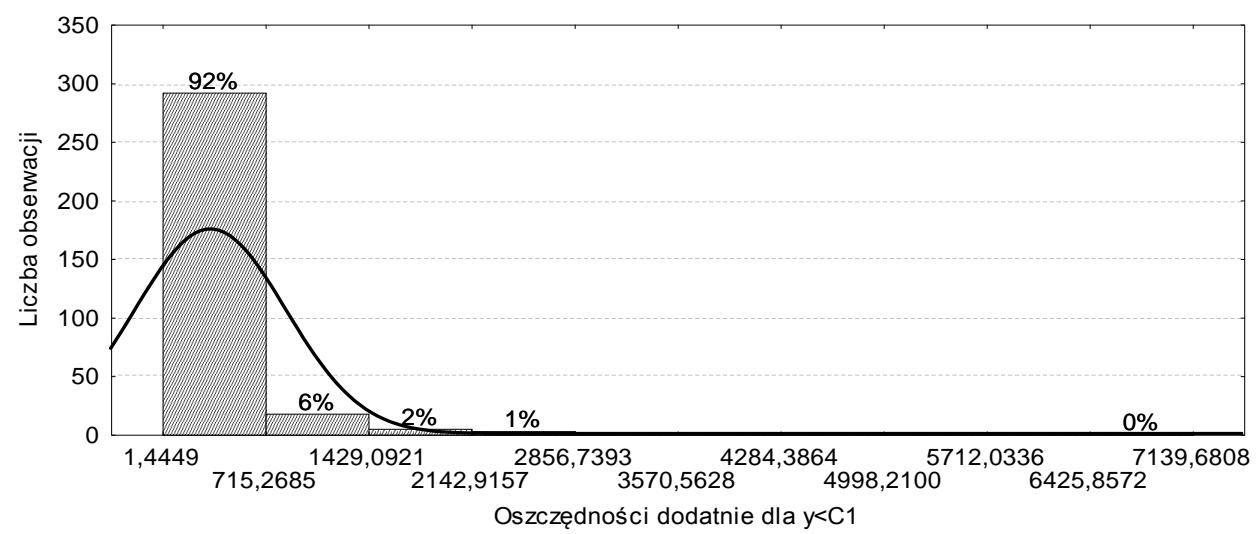


B.

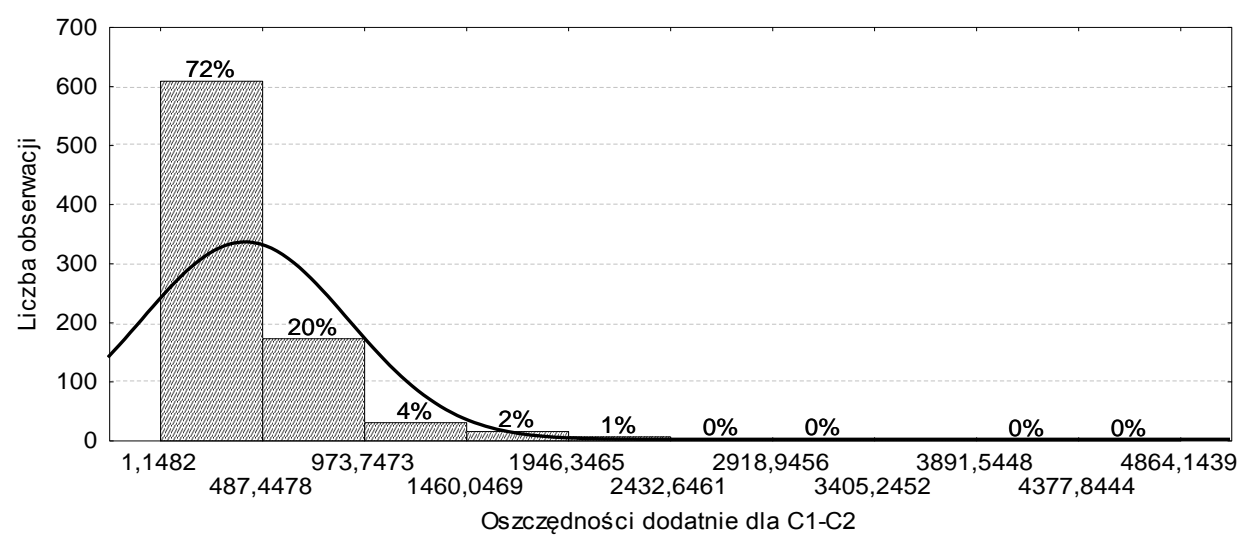

C.

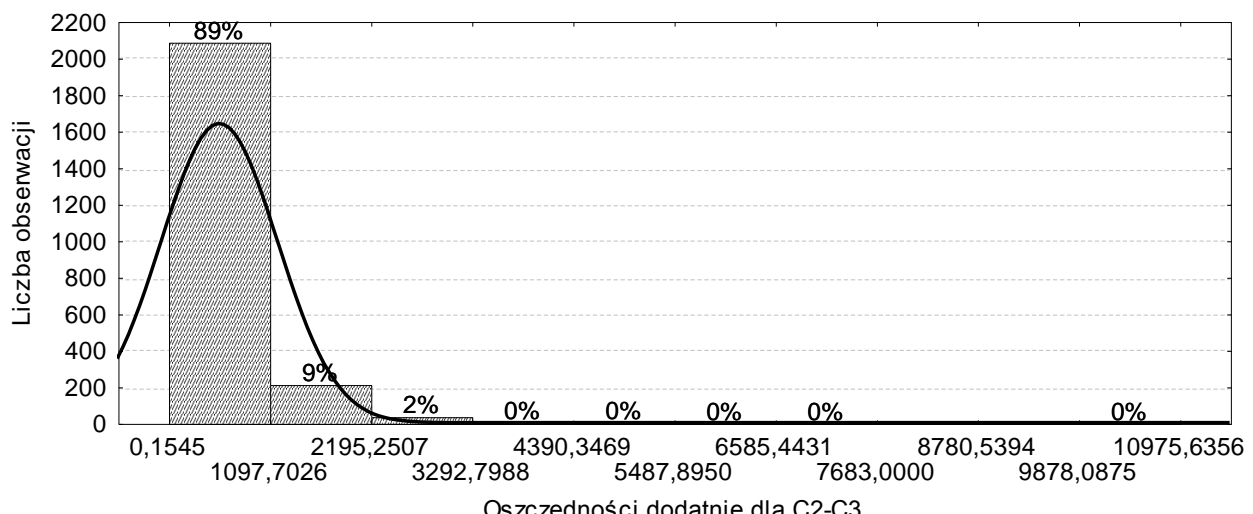

Źródło: opracowanie własne.

\section{PODSUMOWANIE}

Ocena sytuacji materialnej gospodarstw domowych, w tym także uzyskiwanych przez nie dochodów, jest podstawą do podjęcia decyzji dotyczącej przeznaczenia uzyskiwanych dochodów. W miarę wzrostu wartości uzyskiwanego dochodu jego ocena wzrasta, powodując tym samym możliwość pełniejszego zaspokojenia potrzeb, w konsekwencji może to wieść do wzrostu wartości oszczędności. Oczywiste jest, że bogatsze gospodarstwa są w stanie wygenerować oszczędności o wyższej wartości, jednak należy mieć na uwadze, że gospodarstwa dysponujące niskimi dochodami nie tylko mogą kreować oszczędności, ale mogą być też one znaczące. Wynika to przede wszystkich z różnej oceny dochodu, choć może być efektem racjonalnego dysponowania budżetem. Mimo że ankietowane przez GUS gospodarstwa domowe przypisywały poszczególnym ocenom użyteczności dochodu dość zróżnicowane wartości nominalne, to jednak potwierdzona została zależność, że w miarę wzrostu tej oceny, zarówno odsetek, jak i wartość oszczędności wzrastają. Nie wyklucza to 
oczywiście zadłużenia się bardzo bogatych gospodarstw, co jest jednak rezultatem sposobu zbierania danych (według miesięcznej rotacji gospodarstw).

Wyniki przeprowadzonej analizy wskazują na prawidłowość przyjętych hipotez badawczych. Pierwsza z nich zakładała, że osiąganie dochodów ocenianych jako mniej użyteczne może nie wykluczać kreowania oszczędności. Rzeczywiście, 10\% gospodarstw należących do grupy uzyskującej dochody oceniane przez siebie jako „bardzo złe”, kreuje oszczędności (choć $90 \%$ z należących do tej grupy jest zadłużona). W przypadku gospodarstw uzyskujących dochody w przedziale ocenianym przez siebie między „bardzo złe” a „,niewystarczające” odsetek gospodarstw kreujących oszczędności wzrósł do prawie 25\%, a w trzeciej grupie dochodowej - do 40\%. Pomimo wspomnianego spadku odsetka gospodarstw kreujących oszczędności w poszczególnych grupach dochodowych (w stosunku do lat ubiegłych) nie ma podstaw do odrzucenia przyjętej hipotezy badawczej. Warte uwagi są jednak powody, dla których rośnie odsetek zadłużonych gospodarstw, co może stanowić przedmiot odrębnej analizy.

W drugiej hipotezie przyjęto, że wzrastającemu poziomowi użyteczności dochodów towarzyszy wzrastające prawdopodobieństwo kreowania oszczędności, co jest ściśle związane z dokonanym uprzednio wywodem. Wzrost ten w analizowanym 2012 r. jest proporcjonalny (wzrost o około 15\% przy przejściu między grupami). We wcześniejszych latach wzrost ten nie był proporcjonalny i na ogół między pierwszą a drugą grupą dochodową był znacznie wyższy niż między drugą a trzecią. Na przykład w roku 2004 różnica między pierwszą a drugą grupą wyniosła 18\%, między drugą a trzecią zaś $-10 \%{ }^{10}$.

\section{LITERATURA}

[1] Amiel Y., The Subjective Approach to the Measurement of Income Inequality, „Distributional Analysis Research Programme Discussion Papers” London School of Economics, London 1998.

[2] Bernoulli D., Exposition of a new theory on the measurement of risk, „Econometrica” 22/1 (1954) (powtórne wydanie oryginału).

[3] Karta statystyczna gospodarstwa domowego (BR-0la), dział 6: Opinia respondenta o warunkach życia gospodarstwa domowego.

[4] Khaneman D., Theler R.H., Anomalies: Utility Maximization and Experienced Utility, „Journal of Economic Perspectives” 20/1 (2006).

[5] Kot S.M., Ekonometryczne modele dobrobytu, Wydawnictwo Naukowe PWN, Warszawa 2000.

[6] Kot S.M., Modelowanie poziomu dobrobytu. Teoria i zastosowanie, Zakład Narodowy im. Ossolińskich, Wrocław-Warszawa-Kraków 1995.

[7] Plug E.J.S., van Praag B.S.M., Hartog J., Household equivalence scales and household taxation, „Working Paper University of Amsterdam”, Amsterdam 1998.

[8] Schoemaker P.J.H., The Expected Utility Model: Its Variants, Purpose, Evidence and Limitation, „Journal of Economic Literature” 1982/XX.

[9] Szczygieł E., Ocena użyteczności dochodu i jej wplyw na oszczędności gospodarstw domowych, WNT, Warszawa 2014.

${ }^{10}$ E. Szczygieł, op. cit., s. 106-107. 
[10] Van Praag B.M.S., An integration of the two dimensions of the welfare concept, [w:] The Measurement of Household Welfare, red. R. Blundell, I. Preston, I. Walker, Cambridge University Press, Cambridge 1994.

[11] Van Praag B.M.S., Frijters P., The measurement of welfare and well-being. The Leyden approach, [w:] Well-Being. The Fondations of Hedonic Psychology, red. D. Khanemen, E. Diner, N. Schwarz, Russel Sage Foundation, New York 2003.

[12] Van Praag B.M.S., Individual Welfare Functions and Consumer Behavior - a Theory of Rational Irrationality, North-Holland Publishing Company, Amsterdam 1968, Contributions to Economic Analysis, nr 57.

[13] Van Praag B.M.S., Kapteyn A., Further Evidence on The Individual Welfare Function of Income: An Empirical Investigation in The Netherlands, „European Economic Review"1973/4.

[14] Van Praag B. M. S., The Welfare Function of Income In Belgium: An Empirical Investigation, „European Economic Review” 1971/2.

\section{THE SAVINGS OF HOUSEHOLDS WHICH ACHIEVED THE LOW UTILITIES INCOME}

The main aim of the paper is to present the size of the savings that can be created by households which achieved low utilities income. The analysis includes the theoretical basis of the measurement of income utility and presentation of the savings in the group of households which received income referred to as low useful. The empirical part of the article is based on the results of the research project carried out by the "Centre for Education and Enterprise Support" Association under the title "Study of utility of income in Polish households and its impact on the households". Statistical analysis is performed on data from the Household Budget survey conducted by the Central Statistical Office. This article is based on the development of their own CSO figures. GUS is not responsible for the conclusions contained in the publication. The results obtained indicate that the deriving income which are assessed as less useful not necessarily exclude the appearance of savings in such households. The percentage of savers increases with the transition to higher degrees assess the utility of income. Also the nominal value of the savings increase with the transition to a group of households assessing their income as more useful.

Keywords: incomes, savings, households, utility of income, leyden method

DOI:10.7862/rz.2015.hss.27

Przesłano do redakcji: listopad 2014

Przyjęto do druku: lipiec 2015 